NBER WORKING PAPER SERIES

\title{
PUBLIC VS. PRIVATE PROVISION OF CHARITY CARE? EVIDENCE FROM THE EXPIRATION OF HILL-BURTON REQUIREMENTS IN FLORIDA
}

\author{
Douglas Almond \\ Janet Currie \\ Emilia Simeonova \\ Working Paper 15798 \\ http://www.nber.org/papers/w15798 \\ NATIONAL BUREAU OF ECONOMIC RESEARCH \\ 1050 Massachusetts Avenue \\ Cambridge, MA 02138 \\ March 2010
}

The views expressed herein are those of the authors and do not necessarily reflect the views of the National Bureau of Economic Research.

NBER working papers are circulated for discussion and comment purposes. They have not been peerreviewed or been subject to the review by the NBER Board of Directors that accompanies official NBER publications.

(C) 2010 by Douglas Almond, Janet Currie, and Emilia Simeonova. All rights reserved. Short sections of text, not to exceed two paragraphs, may be quoted without explicit permission provided that full credit, including $(\subset$ notice, is given to the source. 
Public vs. Private Provision of Charity Care? Evidence from the Expiration of Hill-Burton

Requirements in Florida

Douglas Almond, Janet Currie, and Emilia Simeonova

NBER Working Paper No. 15798

March 2010

JEL No. I1,I11,I18

\begin{abstract}
This paper explores the consequences of the expiration of charity care requirements imposed on private hospitals by the Hill-Burton Act. We examine delivery care and the health of newborns using the universe of Florida births from 1989-2003 combined with hospital data from the American Hospital Association. We find that charity care requirements were binding on hospitals, but that private hospitals under obligation "cream skimmed" the least risky maternity patients. Conditional on patient characteristics, they provided less intensive maternity services but without compromising patient health. When obligations expired, private hospitals quickly reduced their charity caseloads, shifting maternity patients to public hospitals. There they received more intensive services, but did not experience improvements in health. These results suggest that public hospitals provided services less efficiently than private hospitals constrained to provide charity care.
\end{abstract}

Douglas Almond

Department of Economics

Columbia University

International Affairs Building, MC 3308

420 West 118th Street

New York, NY 10027

and NBER

da2152@columbia.edu

Janet Currie

International Affairs Building

Department of Economics

Columbia University - Mail code 3308

420 W 118th Street

New York, NY 10027

and NBER

jc2663@columbia.edu
Emilia Simeonova

Department of Economics

Tufts University

Medford, MA 02155

and IIES, University of Stockholm

emilia.simeonova@gmail.com 


\section{Introduction}

The provision of charity care, medical care for those who lack insurance and cannot afford to pay for it, is a central issue in the current debate over health care reform in the U.S.. This is not surprising given that the number of U.S. residents without health insurance is projected to increase to 52 million or $19 \%$ of the population this year (Gilmer and Kronick, 2009). At the same time, the proportion of U.S. physicians providing charity care dropped 8 percentage points in the last decade, falling to 68 percent of physicians in 2004-05. Among physicians who practice in a hospital setting, the drop is even larger - from 66\% in 1996-1997 to 54 percent in 2004-2005 (Cunningham and May, 2006).

Historically, different solutions to the charity care problem have been implemented for specific groups. For example, the elderly all receive public health insurance under the Medicare program. Most children are now eligible for insurance coverage under a mix of private and public insurance plans, where the coverage of the public insurance plan (Medicaid) is sometimes substantially better or worse than that of most private plans. And many indigent patients receive charity care, often at public hospitals. Private non-profit hospitals receive substantial tax subsidies in return for an implicit agreement that the hospitals provide public services including the provision of charity care.

One proposal that has been discussed in the context of health care reform is to place explicit requirements to provide charity care on these hospitals. Pear (2009) describes a bipartisan proposal sponsored by Senators Baucus and Grassley to require an explicit amount of charity care in return for getting or keeping tax exempt status. This provision has been vigorously opposed by organizations representing hospitals on the grounds that the current 
system of tax subsidies already successfully encourages hospitals to provide charity care so that quotas would increase the burden on hospital administrators without creating any social benefit.

This paper studies the effects of an earlier program that required private hospitals to provide a fixed percentage of charity care to "pay back" construction subsidies. The Hospital Survey and Construction Act of 1946 was intended to improve hospital infrastructure in underserved areas. It is often referred to as the Hill-Burton Act after its two senate sponsors. The Act provided grants and low-interest loans for hospital construction, and specified that recipients would be obligated to provide charity care for 20 years after the initial funds had been disbursed (see Almond et al., 2007 and Almond, Chay, and Greenstone, 2007 for further discussion). An important point is that over our sample period, Hill-Burton requirements took the form of explicit quotas on the amount of charity care to be provided.

We examine hospitals' responses to the expiration of these requirements using a unique data set of all births in hospitals in Florida between 1989 and 2003. An important feature of these data is that we can track the same mothers over time, and hence we can control for the selection of mothers into different types of hospitals by estimating models with mother fixed effects. We investigate the effects of contract expirations on the services offered by the facilities, the mix of mothers served, procedures, and health outcomes. Furthermore, Florida is a state with an especially large number of uninsured persons. In 2006, 25.3\% of the non-elderly population did not have health insurance coverage compared to $18.1 \%$ nationally. ${ }^{1}$

We find that private hospitals under obligation were indeed constrained by the charity care provisions. However, they selected low risk patients and offered less aggressive (and therefore less expensive) maternity services. When their obligations expired, private hospitals quickly adjusted the mix of services and their caseloads and reduced the amount of charity care

\footnotetext{
${ }^{1}$ Authors' calculations based on the Current Population Survey
} 
provided. Hence, the tax subsidy for non-profit hospitals, which remained in place, was not enough to encourage hospitals to maintain previous levels of charity care.

Private hospitals whose obligations expired reduced the provision of maternity care, and shifted mothers to public hospitals. Perhaps surprisingly, mothers in public hospitals received additional services, but did not benefit from any measureable improvements in outcomes. Thus, the public hospitals provided maternity services to the marginal patient less efficiently than private hospitals that were constrained to serve charity patients. These results provide additional support for solutions to the charity care problem that integrate the uninsured into the mainstream of health care delivery.

If health care reform is successful, the numbers of people without insurance, and thus the need for outright charity care, will be reduced. However, the need will not be eliminated since, for example, undocumented immigrants will not be covered by any current proposals. Moreover, differences in the generosity of health insurance coverage are likely to remain. Our results indicate that it may be socially advantageous to provide public incentives or mandates for private providers to treat those who are underinsured, rather than expanding public provision of care. However it is likely key to our results that, as we discuss below, private hospitals had strong incentives to keep the costs of charity care down, and these incentives may have spilled over onto their treatment of other patients. Another reading of our results is that private hospitals are quick to adjust practices and caseloads in response to financial incentives, so that appropriate incentives are essential to control health care costs.

The rest of the paper is laid out as follows. The next section provides important background information and a discussion of hospital incentives. Section III describes the data 
and Section IV describes our methods. Results are shown in Section V, with some extensions in Section VI. Section VII concludes.

\section{Background on the Hill-Burton Program and Hospital Incentives}

The Hill-Burton Act authorized Federal grants, loans, and loan guarantees to assist states and communities in constructing hospitals and public health centers. By 2000 the Hill-Burton Act had dispensed more than $\$ 4.6$ billion in grants as well as $\$ 1.5$ billion in loans to nearly 6,800 healthcare facilities in over 4,000 communities (Hill and Hill, 2004). To be eligible for HillBurton funds, the hospital could be either a public or not for profit entity. Facilities were initially obliged to make a "reasonable volume" of free services available to persons unable to pay for a period of 20 years. In 1979, “reasonable volume” was defined to be "not less than the lesser of (i) Three percent of its operating costs for the most recent fiscal year for which an audited financial statement is available; or (ii) Ten percent of all Federal assistance provided to or on behalf of the facility, adjusted by a percentage equal to the percentage change in the national Consumer Price Index for medical care between the year in which the facility received assistance or 1979, whichever is later, and the most recent year for which a published index is available."2

The obligation begins when construction of any facility built with Hill-Burton funds is completed. If a facility does not provide the required volume of uncompensated care in any year, then it must make up the difference even if that takes more than 20 years. Over the period under

\footnotetext{
${ }^{2} 42$ C.F.R. $\$ 124.503$ (1979)
} 
consideration, many hospitals converted from non-profit to for-profit status. Nervetheless, these hospitals continued to be obligated by their Hill-Burton requirements ${ }^{3}$.

Although some public hospitals also received funding under Hill-Burton, we focus on the responses of private hospitals. Previous studies have suggested little difference in the behavior of non-profit and for-profit private hospitals (Duggan, 2000; Needleman et al., 1999; Norton and Staiger, 1994; Pauly, 1987); both are constrained by market forces. On the other hand, public hospitals are paid for by the state, city or county, and have an obligation to serve the indigent. If they have a bad year financially, it is likely that their subsidy will be increased, whereas if they have a good year, their subsidy may be decreased. Thus, we expect public hospitals to be much less aggressive in managing their caseloads than private hospitals. In fact, we show below that public hospitals passively adjusted to a reduction in maternity care on the part of private hospitals whose Hill-Burton obligations had expired by increasing their own provision of maternity care.

We can think of private hospitals (hereafter "hospitals") as having a target level of charity care. Frank and Salkever (1991) and Frank, Salkever, and Mitchell (1990) point out that this level can be greater than zero, if for example, providing charity care improves relationships with regulatory agencies, or increases donations to the hospital. These hospital goals may be better served by spreading the same Hill-Burton expenditure over more patients, either because variance in expenditures is reduced or because more patients benefit. If this is the case, then Hill-Burton hospitals will have an incentive to select the lowest expected cost patients for charity

\footnotetext{
${ }^{3}$ The Hill-Burton regulations' provision in such cases is that either the hospital continued to comply with the initial obligations stipulated by the contact signed with the non-profit entity or the federal loan is returned in full to the federal government. The same rule applied to hospital mergers in which one of the entities is under obligation at the time of the merger. The HRSA assured us that there were no cases in Florida in which the for-profit (or merged) hospital opted to return the grant money rather than take on the obligations. The updated list of Hill-Burton facilities and expiration dates was cross-checked with the list of hospital mergers and hospitals that changed to for-profit status to confirm this statement. No discrepancies were found.
} 
care. If the optimal level of charity care is greater than the Hill-Burton requirement, then the obligation's expiration should have no effect. Alternatively, if it is binding then hospitals will reduce charity care when the obligations expire.

It is clear that the obligations were binding. Data on hospitals' financial performance for the period 1979-2003 were obtained from the Agency for Health Care and Administration for the state of Florida. These data include the amounts spent by hospitals every year to meet their Hill Burton requirements and other funds donated or devoted to charity. Figure 1 shows the fraction of total patient revenue devoted to Hill-Burton care by participating hospitals before and after their obligations expired. ${ }^{4}$ The figure shows that hospitals spent close to the expected level of 3 percent of operating costs on Hill-Burton patients in each fiscal year. Since the operating costs generally increase from year to year, it is reasonable to expect that in current-year terms the fraction of costs devoted to Hill-Burton care would be slightly lower than three percent. ${ }^{5}$

One way to change the fraction of charity care patients is to change the mix of services provided. In his analysis of California’s Disproportionate Share (DSH) Program, Duggan (2000) shows that private hospitals that wished to increase their share of indigent patients in order to qualify for payments under the DSH program greatly expanded the number of maternity patients they served. Hospitals preferred maternity patients for two reasons. First, they are generally young healthy women with short expected stays, low expected costs, and a low variance of costs

\footnotetext{
${ }^{4}$ Hospitals that have not finished all of their obligations by the year of the expiration are expected to continue providing Hill-Burton care until those full obligations are met, which accounts for non-zero contributions in the years immediately following expiration. That explains the residual amounts contributed to Hill-Burton charity cases for the first couple of years after the expiration. See 42 C.F.R $\S 124.503$ Compliance levels: (b) Deficits. If in any fiscal year a facility fails to meet its annual compliance level, it shall provide uncompensated services in an amount sufficient to make up that deficit in subsequent years, and its period of obligation shall be extended until the deficit is made up.

${ }^{5}$ A close examination of other sources of charity care in hospitals' financial reports showed no discernible change associated with the expiration of Hill-Burton obligations. There is no evidence that hospitals re-directed uncompensated care cases through other charity programs to offset the lack of Hill-Burton designated funds.
} 
relative to (for example) elderly diabetics or heart patients. Second, expanded Medicaid coverage of pregnant women made them more lucrative than other categories of indigent patients. In Florida, the fraction of deliveries paid for my Medicaid rose from 25\% to 36\% between 1988 and 1991 when the income threshold for Medicaid was raised from $100 \%$ to $150 \%$ of poverty (Marquis and Long, 1999).

A simple calculation illustrates that by expanding maternity care, a hospital could meet its Hill-Burton requirements without bearing much risk of having to provide any additional uncompensated care above the requirement. On average, hospitals in our sample devoted about $\$ 221,100$ (2008 US dollars) per year to Hill-Burton charity care. ${ }^{6}$ In 2008, the average inpatient charge for a delivery in Florida hospitals was approximately $\$ 2500$, ranging from an average low charge of $\$ 1670$ to an average high charge of $\$ 3340 .^{7}$ The average number of deliveries in hospitals under Hill-Burton obligation in our sample is 760. If all Hill-Burton funds were used for maternity care, between 9\% (using the average high charge) and 17\% (using the average low charge) of deliveries would be accounted by the Hill-Burton program while the deliveries of most other low income mothers would be compensated by Medicaid. ${ }^{8}$ A hospital might even be strategic about which cases it classified under Hill-Burton, placing women who did not qualify for Medicaid, or patients who did not cooperate with hospital efforts to help them to become covered, under Hill-Burton.

\footnotetext{
${ }^{6}$ Authors' calculations based on hospital financial reports.

${ }^{7}$ The Florida Agency for Health Care Administration reports low and high charge averages for each hospital in the year. The "low" value is represented by the 25th percentile and the "high" value is represented by the 75th percentile of charges. 50 percent of the charges billed are between the 25th and 75th percentile. All charges data come from the Florida Agency for Health Care Administration Report, and are available at http://www.floridahealthfinder.gov ${ }^{8}$ Even deliveries to undocumented women were covered by Medicaid.
} 
In keeping with Duggan's results and this illustration, Figure 2 shows that private hospitals in Florida that were initially covered by Hill-Burton were much less likely to offer maternity services after their Hill-Burton obligation expired.

Finally, it may be difficult for hospitals to offer a different menu of services to different groups of women. Suppose, for example, that a hospital may choose to offer aggressive or conservative maternity services. Aggressive hospitals will routinely conduct additional tests and will perform C-sections in marginal cases. Conservative hospitals will conduct fewer tests and will be less likely to perform C-sections in marginal cases. There is a good deal of evidence that doctors and hospitals are responsive to financial incentives, and are more likely to perform Csections when C-sections are more highly compensated relative to normal deliveries (Currie, Gruber and Fischer 1995, Gruber, Kim, and Mayzlin 1998, Currie and MacLeod, 2008). Further, it is thought that the marginal C-section in the U.S. is unnecessary: A Healthy People 2010 goal is to reduce the rate of C-sections from over 30 percent to 15 percent. Baicker, Buckles and Chandra (2005) find that the marginal C-section is performed on a medically less appropriate patient and that only 25 percent of the geographical variation in C-section rates can be explained by differences in risk factors.

To capture the idea that hospitals choose to offer either aggressive or conservative maternity services in order to maximize profits, suppose that it is profitable for a hospital serving privately insured women to offer aggressive services to maternity patients:

(1) $M\left(p_{a}-c_{a}\right)>M\left(p_{c}-c_{c}\right)$, where $\mathrm{M}$ is the number of privately insured maternity patients, $\mathrm{p}_{\mathrm{a}}$ is the market price of aggressive services, $c_{a}$ is the cost of providing aggressive services, $p_{c}$ is the market price of a 
conservative bundle of maternity services and $c_{c}$ is the cost of providing conservative maternity services. Moreover, $\mathrm{p}_{\mathrm{a}}>\mathrm{p}_{\mathrm{c}}$ and $\mathrm{c}_{\mathrm{a}}>\mathrm{c}_{\mathrm{c}}$.

If it is necessary to offer the same menu of services to all patients, then as the number of Hill-Burton (HB) patients rises, it may become profitable for the hospital to switch to the conservative bundle of services. This will be the case if:

(2) $M\left(p_{c}-c_{c}\right)-H B c_{c}>M\left(p_{a}-c_{a}\right)-H B c_{a}$.

The cross-over occurs when $(H B / M)\left(c_{a}-c_{c}\right)=\left(p_{a}-c_{a}\right)-\left(p_{c}-c_{c}\right)$; That is, when the share of HillBurton patients, (HB/M) exceeds $\left[\left(\mathrm{p}_{\mathrm{a}}-\mathrm{p}_{\mathrm{c}}\right)-\left(\mathrm{c}_{\mathrm{a}}-\mathrm{c}_{\mathrm{c}}\right)\right] /\left(\mathrm{c}_{\mathrm{a}}-\mathrm{c}_{\mathrm{c}}\right)$. This situation is illustrated in Figure 3.

The situation is slightly complicated by the presence of Medicaid patients. In Florida, Medicaid reimburses at the same rate for C-sections and for vaginal deliveries. We can capture the role of Medicaid patients by assuming that hospitals are always paid $\mathrm{p}_{c}$ for Medicaid patients whether they provide conservative or aggressive care. In this case, whenever condition (2) holds hospitals will still prefer to offer conservative care even with Medicaid patients since $\left(\mathrm{p}_{\mathrm{c}}-\mathrm{c}_{\mathrm{c}}\right)>$ $\left(p_{c}-c_{a}\right)$.

This simple model assumes that faced with two women with the same indications, different hospitals can make different choices about the bundle of services to be offered and that the marginal woman does not choose the hospital on the basis of the aggressiveness of the care, other things being equal.

Figures 4 and 5 examine the use of primary C-section, and the admission of high risk maternity cases in hospitals that ever had Hill-Burton obligations, before and after the expiration of those obligations. The figures show an increase in the admission of high risk patients, and an increase in the use of C-sections after expiration, as the model would predict. 
In summary, we expect that Hill-Burton obligations will be associated with a higher probability that a hospital has a maternity ward and with fewer aggressive procedures for maternity patients. The expiration of Hill-Burton requirements are therefore likely to be accompanied by a rapid shifting of indigent patients from private to public hospitals and with the closure of maternity care units. Whether this results in individuals receiving more aggressive services or not depends on whether the public hospitals that absorb the indigent patients are more likely to be conservative or aggressive compared to the private hospitals. And whether changes in procedures affect health will depend on whether the marginal procedures are necessary or not: Increases in the use of necessary procedures will improve infant health outcomes, while increases in the use of unnecessary procedures are likely to have little effect on infant health.

\section{Data}

Data for this study were drawn from the American Hospital Association's (AHA) hospital files, the Florida vital statistics and the federal Health Resources and Services Administration (HRSA) Hill Burton registry files. The AHA files contain data on the total number of admissions in the hospital, hospital ownership status, the number of Medicaid patients and whether the hospital offers maternity services. Many hospitals change names over time, but the AHA files conveniently maintain a unique hospital identifier that allows tracking the same hospital across different names.

HRSA provided us with the latest list of Hill-Burton expiration dates for hospitals in Florida. It is important to work with the most updated information on hospital obligations since the periods may be extended if a facility is found to have been out of compliance in some years. Obligations only start once the hospital has initiated the project for which the funds were 
provided initially. The funds intended to reach the hospitals were slow to arrive from D.C. and even slower to process through the local authorities. The hospitals then had to start their own construction and expansion plans, which created further delays. We found that a number of hospitals that should have finished their 20-year obligation periods based on the year in which the contract was signed were still under obligation a few years later.

Hospitals are coded as being under Hill-Burton obligation if the year when the birth occurred is before or the same as the calendar year in which the obligation expired. Hence the last births that are considered to have occurred in a hospital under obligation are in the last calendar year of the Hill-Burton contract. Table 1 shows the number of expirations of HillBurton obligations and the number of births in hospitals covered by Hill-Burton obligations from 1989 to 2003. Over our sample period the fraction of births in hospitals covered by Hill-Burton obligations declined from almost 18 to just over 2 percent of all births, due to these expirations.

The Florida Vital Statistics record all live births between 1989 and 2003. Confidential data including mothers' names and birth dates were used to construct a panel data set linking births to the same mother over time. The Natality data are very rich, and include information about the mother's age, education, race and ethnicity; the child's gender, birth order, and birth spacing; whether it was a multiple birth; prenatal care; risk factors for the pregnancy; complications of labor and delivery; and procedures used at the time of the birth in addition to information about infant outcomes including gestational age and APGAR scores. Natality data has been matched to data on infant mortality so that we can also identify infants who die before age one. We restrict the sample to singleton births and in most of our analyses, we focus on mothers with at least two births in the sample. 
The Vital Statistics Natality data contain the name and the county of the hospital in which the birth took place. We use these fields to match the natality data with the AHA hospital level data and the HRSA data about Hill-Burton expiration dates. ${ }^{9}$

Table 2 provides an overview of our data. The first two columns show a comparison of means for the full sample of all singleton births in our sample, and means for births to mothers who have two or more singleton births in the sample. It is the latter group that we will focus on in the remainder of the paper. Children born to mothers with more than one birth in the sample are likely to have had better birth outcomes, and are somewhat less likely to have had a C-section (15.3\% vs. $12.0 \%)$. Women with more than one birth are slightly younger, but more educated. They are more likely to deliver in hospitals with Hill-Burton obligations.

Columns 3 through 5 show means for private hospitals and then for two subsets of private hospitals: Those that ever had Hill-Burton obligations, and those that had Hill-Burton obligations at the time of the birth. Means are shown only for mothers with more than 1 birth in the sample. Mothers giving birth in hospitals under obligation are less likely to be black and Hispanic and more likely to have less than a high school education than other mothers giving birth in private hospitals. They are also a little younger on average and less likely to have received adequate prenatal care.

However, they are also less likely to be high risk. We consider a pregnancy to be high risk if one of the following 15 conditions was indicated as a pregnancy risk factor on the birth certificate: maternal anemia, cardiac conditions, lung disease, diabetes, genital herpes, hydramnios (too much amniotic fluid), haemorraging, hypercalemia (elevated potassium levels

\footnotetext{
${ }^{9}$ As a check on the consistency of the merge, the number of births in each facility was cross-checked between the Florida Vital Statistics and the AHA records. Every hospital listed in the Vital Statistics files was found in the AHA files. When there were two hospitals with the same names we used the number of births and the city of birth to establish the identity of the hospital. Data from the naval hospitals system in Florida were dropped because the Vital statistics data did not contain enough information on the facility to determine which naval hospital hosted the birth.
} 
in the blood), eclampsia (elevated blood pressure during or before labor), incompetent cervix, previous infant over 4000 grams, renal failure, previous preterm pregnancies, uterine infections, and other maternal risks not classified above.

Mothers in hospitals under obligation have similar rates of complications of labor and delivery to other mothers in private hospitals. We consider the following conditions to be complications of labor and delivery: premature rupture of membranes, abruptio placenta (separation of the normally located placenta after the 20th week of gestation and prior to birth), placenta previa (placenta is lying unusually low in the uterus), precipitous labor, breech (when the baby is not head down), fetal distress, excessive bleeding, prolonged labor, meconium (the baby inhales a mixture of amniotic fluid and fetal excretion), seizures during labor, dysfunctional labor, febrile labor, cephalopelvic disproportion (when a baby's head or body is too large to fit through the mother's pelvis), complications related to anesthesia, other complications not mentioned above.

If the mothers giving birth in hospitals under Hill-Burton obligation are relatively low risk, then perhaps it is unsurprising that their outcomes in terms of low birth weight and low APGAR scores are similar to those in other private hospitals (although there is a slightly elevated risk of infant mortality). A comparison of the last two columns suggests that once the HillBurton obligation expired, hospitals were more willing to accept high risk patients who were more likely to give birth to premature and/or low birth weight babies with low APGAR scores. ${ }^{10}$

\footnotetext{
${ }^{10} \mathrm{An}$ infant is considered to be of low birth weight if the weight at birth is lower than 2500 grams. A birth is considered premature if the gestation period was less than 37 weeks. An APGAR score or less than 9 is considered low.
} 


\section{Methods}

We first examine responses to Hill-Burton expiration at the hospital level, and then examine the consequences for individual-level outcomes. Hospital-level data is formed by aggregating the individual birth records to the hospital level and merging it with information about the hospital. The hospital-level regressions take the following form:

(1) HospChar $_{\mathrm{ht}}=\alpha+\beta^{*}$ OBLIGATION $\mathrm{ht}_{\mathrm{ht}}+\eta_{\mathrm{t}}+\mu_{\mathrm{h}}+\varepsilon_{\mathrm{ht}}$,

where HospChar ht $_{\text {is }}$ a hospital characteristic such as whether it offers maternity care, or the fraction of minority maternity patients that it serves, OBLIGATION is an indicator equal to one if the hospital is under Hill-Burton obligation to provide uncompensated care and 0 otherwise, $\eta_{\mathrm{t}}$ is a vector of year indicators and $\mu_{\mathrm{h}}$ is a vector of hospital indicators and $\varepsilon_{\mathrm{ht}}$ is a hospital-year specific error term. Year indicators control for unrestricted year-to-year variation in average hospital characteristics. The inclusion of hospital fixed effects allows us to compare the same hospitals before and after the expiration of Hill-Burton obligations.

In order to examine individual-level outcomes we first estimate maternal fixed effects models of the following form:

(2) Outcome $_{i t}=\alpha_{\mathrm{i}}+\beta^{*}$ OBLIGATION $_{\mathrm{it}}+v \mathrm{X}_{\mathrm{it}}+\eta_{\mathrm{t}}+\varepsilon_{\mathrm{it}}$,

where Outcome it $_{\text {is }}$ an individual-level outcome such as whether the baby was premature, or whether there was an infant death, OBLIGATION and $\eta_{\mathrm{t}}$ are defined as above, $\alpha_{\mathrm{i}}$ is a vector of indicators for each mother and $\varepsilon_{\mathrm{it}}$ is an individual and year specific error term. The vector $\mathrm{X}_{\mathrm{it}}$ includes time-varying characteristics of the birth including the child's gender; birth order indicators $\left(1^{\text {st }}, 2^{\text {nd }}, 3^{\text {rd }}, 4^{\text {th }}\right.$ or higher order birth); and indicators for birth interval.

The inclusion of maternal fixed effects (the $\alpha_{\mathrm{i}}$ ) allows us to control for constant unobserved characteristics of mothers that might affect both their choice of hospital and birth 
outcomes. For example, a woman might have a health condition that made all of her pregnancies high risk. However, it is possible that a woman will have risk factors for one pregnancy and not another. Our hospital-level investigations will show that Hill-Burton hospitals are less likely to admit high-risk mothers. If hospitals can observe information about whether a particular pregnancy is likely to be high risk, then a woman with one high risk and one low risk pregnancy may be less likely to deliver the high risk baby in a Hill-Burton hospital. Such a pattern would tend to bias the estimated effects of Hill-Burton obligations towards finding positive effects on infant health outcomes. Moreover, fixed effects models can produce coefficients that are biased towards zero in the presence of measurement error, and there is likely to be measurement error in gestational age.

In order to take account of these potential issues, our preferred estimates are based on instrumental variables models with maternal fixed effects. These models are of the form:

(3) Outcome $_{i t}=\alpha_{i}+\beta^{*} \mathrm{P}\left(\right.$ OBLIGATION $\left._{\mathrm{it}}\right)+v \mathrm{X}_{\mathrm{it}}+\eta_{\mathrm{t}}+\varepsilon_{\mathrm{it}}$, where $\mathrm{P}\left(\mathrm{OBLIGATION}_{\mathrm{it}}\right)$ is the predicted probability that the baby was born in a hospital under obligation from a first stage regression of the form:

(4) $\mathrm{P}\left(\right.$ OBLIGATION $\left.{ }_{\mathrm{it}}\right)=\alpha_{\mathrm{i}}+\beta^{*}$ FRAC_HB $_{\mathrm{it}}+v \mathrm{X}_{\mathrm{it}}+\eta_{\mathrm{t}}+\varepsilon_{\mathrm{it}}$, where FRAC_HB $\mathrm{B}_{\mathrm{it}}$ is the fraction of births that are in Hill-Burton obligated hospitals at time $t$ in the county in which we first observed the mother giving birth.

The idea behind this instrument is that while the mother's current county is endogenous, the county in which we first observe her is controlled for by the inclusion of the mother fixed effects. The fraction of births in Hill-Burton obligated hospitals in this county will vary over time primarily because of Hill-Burton expirations, which are exogenous to the characteristics of any particular mother. Hence, FRAC_HB $B_{i t}$ should satisfy the criterion for a valid instrument in 
that it should be predictive of $\mathrm{P}\left(\mathrm{OBLIGATION} \mathrm{it}_{\mathrm{it}}\right)$ without having any direct effect on birth outcomes other than through its effects on the probability that a particular birth takes place in a hospital under obligation.

For ease of computation, we have estimated (3) using a two step method in which we first calculate P(OBLIGATION $\left.{ }_{\mathrm{it}}\right)$, and then insert it in the regression. Standard errors are calculated using the bootstrap and are clustered at the hospital level in order to take account of potential correlation in the unobservables within the same hospital.

\section{Results}

Estimates of the effects of Hill-Burton obligations on hospital behavior from models with hospital fixed effects (equation (1)) are shown in Table $3 .{ }^{11}$ The first column shows estimates from a model estimated over all hospital-years, examining the probability that a private hospital offers maternity care. Consistent with Duggan (2000), hospitals that were constrained to offer charity care were more likely to have a maternity ward than other hospitals. The next two columns provide some evidence about the types of services offered to patients for all hospitals that had 100 or more deliveries in a year. Conditional on accepting maternity patients, HillBurton hospitals were less likely to perform primary C-sections, and much less likely to report that mothers had any complications. We focus on primary C-sections because doctors have less discretion about whether to perform a repeat C-section. ${ }^{12}$

\footnotetext{
${ }^{11}$ For reference, ordinary least squares models of health outcomes without fixed effects are show in Appendix Table 1. They show a similar pattern with reductions in prematurity, but no change in infant deaths, low birth weight, or low apgar scores.

${ }^{12}$ It is possible to have a vaginal birth after C-section (VBAC). However, an anesthetist must stand by in case the VBAC fails and an emergency C-section becomes necessary. Many hospitals are unable or unwilling to offer this service. Moreover, given the risk attendant on VBAC, it is not sure whether a secondary C-section or a VBAC is the more "aggressive" procedure in terms of our model. In our data, we observe 107,218 mothers who had a primary C-section and went on to have a second birth in our sample. Of these, $82 \%$ had another C-section. Alternatively, since the method of delivery after a primary C-section can only be listed as a secondary C-section or a
} 
A natural question to ask is whether these differences in procedures reflect differences in the mothers admitted to the hospitals. As Table 2 suggested, it appears that hospitals under obligation were much less likely to admit patients with known risk factors for the pregnancy. We do not find evidence however, that hospitals screened patients on the basis of race, ethnicity, or education. Hence, it appears that Hill-Burton hospitals were selecting patients primarily on the basis of medical risk rather than demographics. Consistent then with the model outlined above, hospitals subject to Hill-Burton requirements welcomed maternity patients, but only relatively healthy ones.

These findings about patient selection suggest that we need to look to individual-level data in order to understand the implications of Hill-Burton for changes in the treatment of an individual mother. Table 4 examines the sub-sample of mothers who had at least one delivery in a Hill-Burton hospital and looks at what happens to their choice of provider if the Hill-Burton requirement expires before a subsequent birth. The models include mother fixed effects. Table 4 shows that these women are very likely to have had to change hospitals, and that a considerable fraction of them switched to public hospitals. These results show clearly that the expiration of Hill-Burton obligations compelled many women who had delivered in private hospitals to switch to the public sector for their deliveries.

Table 5 shows some initial results for individual-level outcomes. The odd numbered columns show mother fixed effects estimates, while the even numbered columns show mother fixed effects-instrumental variables estimates. The estimated first stage showed that the fraction of births in Hill-Burton obligated hospitals in the mother's first observed county of residence is strongly predictive of her current birth being covered by Hill-Burton. The coefficient of .984

VBAC, we can calculate Secondary/(Secondary+VBAC). This rate is $80.5 \%$ confirming that most mothers who have a primary C-section have subsequent deliveries by C-section. 
(standard error .002) in the first stage implies that a 10 percentage point increase in the fraction of births covered would increase the probability of the index birth being in a covered hospital by about $10 \%$.

The first panel of Table 5 suggests that giving birth in a Hill-Burton obligated hospital had no effect on most birth outcomes: There is no significant effect on the incidence of low birth weight or the probability of infant death. The probability of an APGAR score less than 9 falls with Hill-Burton in the fixed effects, but the standard errors increase in the fixed effects-IV model to the extent that the estimate is no longer statistically significant. Surprisingly, given the other results, there does appear to be a substantial negative effect on the probability of prematurity. Moreover, the estimated coefficient is larger in absolute value in the fixed effectsIV model, which is consistent with our conjecture about the direction of potential bias in the mother fixed effects models. (Appendix Table 1 shows that the same result obtains in OLS regressions - Hill Burton seems to be associated with a decrease in prematurity).

The second panel probes the prematurity result by asking whether prematurity is reduced in each of several categories: Less than 32 weeks; between 32 weeks and 35 weeks, or between 35 and 37 weeks. It appears that the reduction occurs only between 35 and 37 weeks. The last two columns also show that the reduction in prematurity is entirely among infants who are not low birth weight.

This pattern suggests that the reduction in prematurity at Hill-Burton hospitals that occurs without improvement in any other infant health outcome could be reflective of a reduction in Csections. Scheduled C-sections are normally performed slightly before full term to avoid the possibility that a woman will go into labor before the C-section can be performed. 
Table 6 confirms that children born in a hospital subject to Hill-Burton obligations are less likely to be delivered via primary C-section. Table 6 also shows that there is no effect of Hill-Burton obligations on the prevalence of complications or risk factors once the characteristics of mothers are adequately controlled. That is, Table 3 showed that hospitals subject to HillBurton were more likely to admit uncomplicated, low-risk cases. Table 5 controls for this type of selection using our fixed effects-IV specification. The results in Table 6 suggest that as Baicker, Buckles and Chandra (2005) argue, the marginal C-section that is foregone in the HillBurton hospital would have been conducted on a medically inappropriate patient-i.e. one who had no complications or risk factors!

\section{Extensions}

We have estimated separate models for African-Americans and Hispanics. These groups may be of particular interest since African-Americans tend to have worse average birth outcomes other things being equal, while Hispanics tend to have better outcomes, other things being equal but are more likely to be undocumented. Since undocumented immigrants are not eligible for Medicaid coverage of their pregnancies in Florida (though labor and delivery is covered), access to charity care under Hill-Burton may have been particularly important for Hispanic mothers.

Appendix Tables 2 through 4 indicate that the effects for African-Americans are quite

similar qualitatively to those we have discussed above. Hill-Burton is associated with a reduction in prematurity which is concentrated among infants who were between 35 and 37 weeks gestation, and which may be accounted for by a decrease in C-section rates when hospitals are under Hill-Burton obligation. 
The effects for Hispanics are less clear. There is a much larger decrease in prematurity, (coefficient of -.042 compared to -.017 for the full sample). The reduction is statistically significant only for infants between 32 and 35 weeks gestation, although the point estimate is much larger for the reduction in prematurity between 35 and 37 weeks (-.017 for 32-35 vs. -.033 for 35-37). However, in contrast to the results for blacks and non-Hispanic whites, there is no change in primary C-section rates associated with Hill-Burton for Hispanics. A possible explanation is that hospitals have little incentive to perform C-sections on mothers without insurance with or without Hill-Burton.

\section{Conclusions}

If health care reform is successful, then in future there will be many fewer uninsured patients. However, given rising health care costs, it is likely that a considerable number of people will remain underinsured and it is of interest to consider how their medical needs can best be served. The results in this paper suggest, perhaps surprisingly, that it can be better to require private providers to serve the underinsured, rather than serving them in separate public facilities. Private providers confronted with charity patients have an incentive to provide care in the most efficient way possible. Moreover, changes in procedures that are adopted in order to cope with charity patients may spillover to fully-insured patients, resulting in further efficiencies. It is striking to see how quickly private hospitals responded to changes in their incentives upon the expiration of Hill-Burton requirements.

On the other hand, public facilities have little incentive to provide care in the lowest cost manner. Still, it is clear that private providers steer clear of the highest risk charity patients, so 
that a public safety net may remain necessary even when private providers handle many of the lower risk charity cases.

An important caveat is that we focus on one condition and one procedure (C-section). While child birth is a common and important cause of hospitalization, it will be important to determine whether the same pattern is observed for others conditions and procedures. 


\section{References}

Almond, Douglas Kenneth Y. Chay, Michael Greenstone, Stacy Sneeringer, and Melissa Thomasson (2007) "The 1946 Hospital Construction Act and Infant Mortality in the United States after World War II,” Working Paper

Almond, Douglas, Kenneth Chay and Michael Greenstone (2007) "Civil Rights, the War on Poverty, and Black-White Convergence in Infant Mortality in the Rural South and Mississippi," MIT Department of Economics Working Paper No. 07-04 .

Baicker, Katherine, Kasey S. Buckles, and Amitabh Chandra (2006) "Geographic Variation in the Appropriate Use of Cesarean Delivery.” Health Affairs, Vol 25 (5), pp. 355-367.

CBO TESTIMONY Statement of Robert D. Reischauer Deputy Director Congressional Budget Office Before the Subcommittee on Housing and Community Development Committee on Banking, Finance and Urban Affairs U.S. House of Representatives May 17, 1979

Cunningham, Peter J. and Jessica H. May (2006) “A Growing Hole in the Safety Net: Physician Charity Care Declines Again” Center for Studying Health System Change Tracking Report No. 13 March 2006

Currie, Janet and Bentley McLeod (2007) “ First Do no Harm? Tort Reform and Birth Outcomes,” forthcoming, Quarterly Journal of Economics

Currie, Janet and John Fahr "Hospitals, Managed Care, and the Charity Caseload in California,“ UCLA Mimeo October 2001

Currie, Janet \& Gruber, Jonathan \& Fischer, Michael, 1995. "Physician Payments and Infant Mortality: Evidence from Medicaid Fee Policy," American Economic Review, American Economic Association, vol. 85(2), May 1995

Denise M. Oleske, Marta L. Branca, Julie B. Schmidt, Richard Ferguson, Edward S. Linn “A comparison of capitated and fee-for-service Medicaid reimbursement methods on pregnancy outcomes” Health Services Research, April, 1998

Department of Health and Human Services Office of Inspector General "Public Health Service's Oversight of the Hill-Burton Program” August, 1992; OIE-05-90-00260

Dorn, Stan (2008) "Uninsured and Dying Because of It: Updating the Institute of Medicine Analysis on the Impact of Uninsurance on Mortality,” Urban Institute, February 2008 (http://www.urban.org/UploadedPDF/411588_uninsured_dying.pdf)

Duggan, Mark (2000) "Hospital Ownership and Public Medical Spending” The Quarterly Journal of Economics, Vol. 115, No. 4 (Nov., 2000), pp. 1343-1373 
Frank, Richard G and David S. Salkever (1991) "The Supply of Charity Services by Nonprofit Hospitals: Motives and Market Structure“The RAND Journal of Economics, Vol. 22, No. 3 (Autumn, 1991), pp. 430-445 Frank and Salkever, 1991

Frank, Richard, David Salkever, and Jean Mitchell. "Market Forces and the Public Good: Competition Among Hospitals and Provision of Indigent Care", Advances in Health Economics and Health Services Research, 11, 1990, 159-183.

Gruber, Jonathan, John Kim, and Dina Mayzlin "Physician fees and procedure intensity: the case of cesarean delivery” Journal of Health Economics 18, 1999.473-490

Guendelman , D . Thornton , J . Gould , N . Hosang (2006) "Obstetric complications during labor and delivery: Assessing ethnic differences in California” Women's Health Issues, Volume 16 , Issue 4, Pages $189-197$ S .

Hill, Kathleen and Gerald N. Hill Encyclopedia of Federal Agencies and Commissions, Facts on File, Washington, DC, 2004

Lamphere J. et al., “Reforming the Health Care System: State Profiles, 1998” Washington: AARP, 1998, 38-43

Marquis MS and Long SH, Medicaid eligibility expansion in Florida: effects on maternity care financing and the delivery system, Family Planning Perspectives, 1999, 31(3):112-116 \& 121.

Needleman, Jack et al (1999) "Uncompensated Care and Hospital Conversions in Florida," Health Affairs; July/August 1999, 18, 4

Norton, Edward and Douglas Staiger (1994) "How Hospital Ownership Affects Access to Care for the Uninsured” The RAND Journal of Economics, Vol. 25, No. 1 (Spring, 1994), pp. 171-185

Pauly, Mark (1987) “Nonprofit Firms in Medical Markets” The American Economic Review, Vol. 77, No. 2, Papers and Proceedings of the Ninety-Ninth Annual Meeting of the American Economic Association (May, 1987), pp. 257-262

Pear, Robert. "Hospitals Mobilizing to Fight Proposed Charity Care Rules,” New York Times, June 1, 2009. www.nytimes.com/2009/06/01/us/politics/01health.html.

Perlstadt, Harry. "The Development of the Hill-Burton Legislation: Interests, Issues and Compromises." Journal of Health and Social Policy 6, no. 3 (1995): 77-96

Public Citizen. Public Citizen's Research Group Report on Questionable Hospitals (Washington D.C.: Public Citizen) July 2001

The University of Pennsylvania Law Review, "The Propriety of Reimbursement by Medicare for Hill-Burton Free Care” University of Pennsylvania Law Review, Vol. 130, No. 4 (Apr., 1982), 
pp. $892-918$ 
Figure 1: Hill-Burton as proportion of total patient expenses

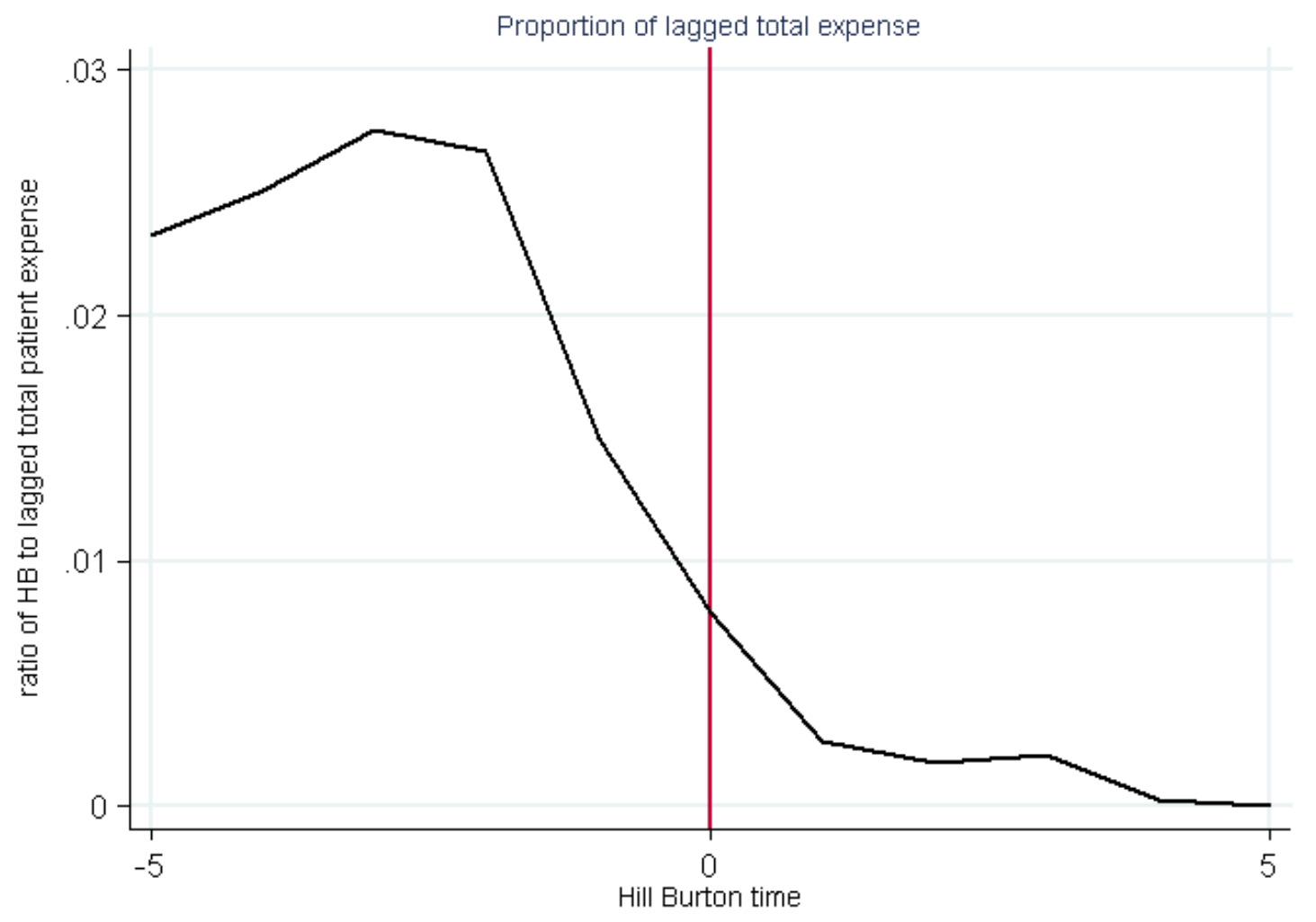

Note: The figure is constructed based on ratios of Hill Burton expenses to lagged total patient expense from hospitals' financial data. Data on hospitals' financial statements come from the Florida Agency for Health Care Administration. Data on two hospitals that had Hill-Burton obligations were excluded from the sample because recorded rates of Hill-Burton expenditures in the $4^{\text {th }}$ year after expiration of the obligations were $33 \%$ and $66 \%$ respectively. HRSA overseers confirmed that these were data entry errors. 
Figure 2: Presence of maternity ward as a function of Hill Burton obligations status

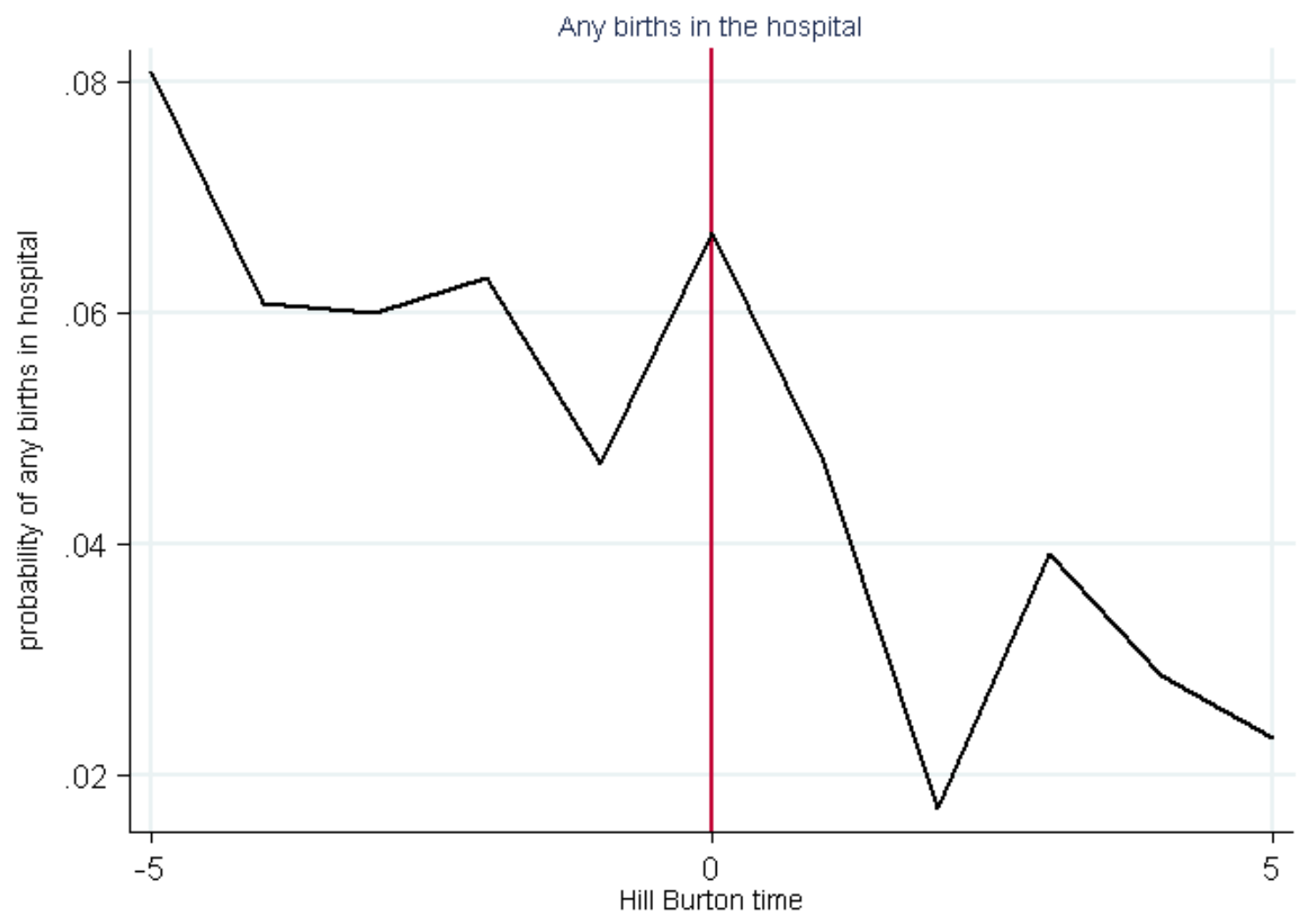

Note: The figure is based on mean residuals relative to the time that Hill Burton obligations expired. The residuals were obtained from a linear probability regression of the outcome variable ( 0 if there are no births in the hospital-year observation, 1 if there are births) on hospital and year fixed effects. The sample of hospitals included in the regression is restricted to 1495 private hospitals and the time period is 1989-2003. Only residuals for hospitals that experienced a HillBurton expiration are included. Data on hospital operations come from the Florida Vital statistics and the American Hospital Association Hospital Survey. 
Figure 3: Share of Hill Burton patients and Hospital Care Regime Choice

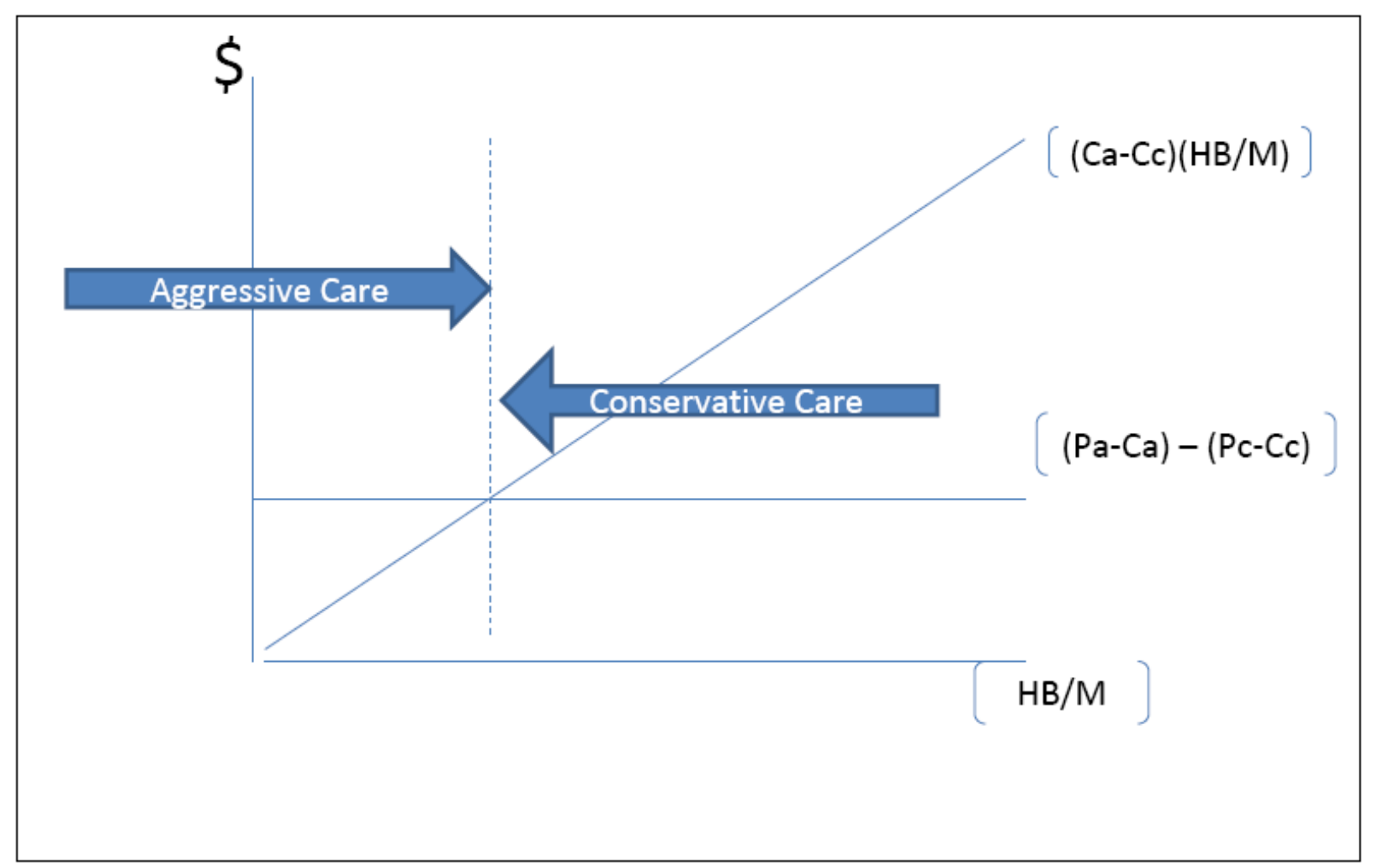


Figure 4: Primary C-Section Rates and Hill Burton Expiration

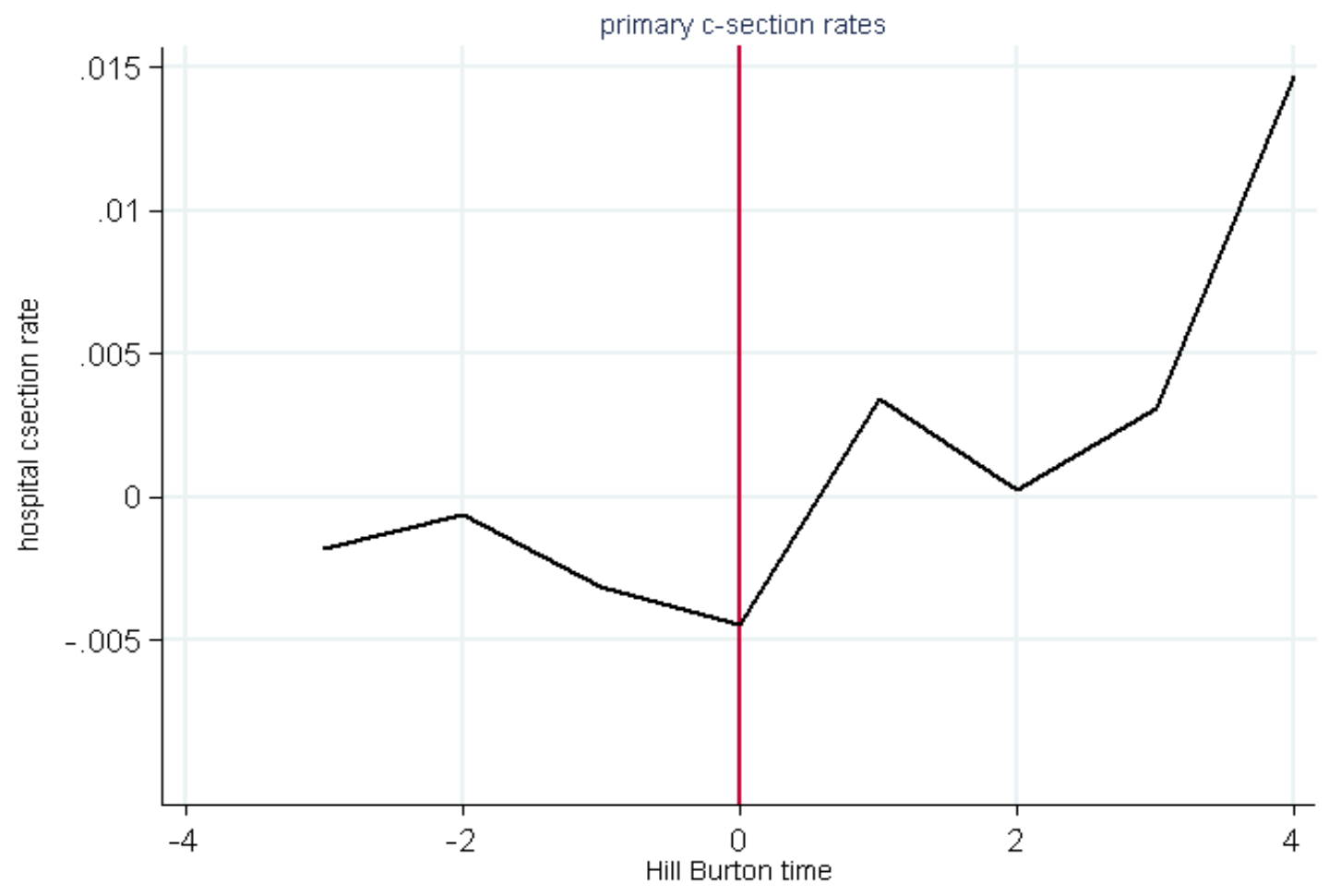

Note: Plots based on yearly averages of residuals from hospital-level regression of outcome on hospital and year fixed effects. Residuals are averaged across hospitals for every year of Hill-Burton obligation; balanced sample for -3 to +4 years after HB expiration. 
Figure 5: Fraction of High Risk Cases and Hill-Burton Expiration

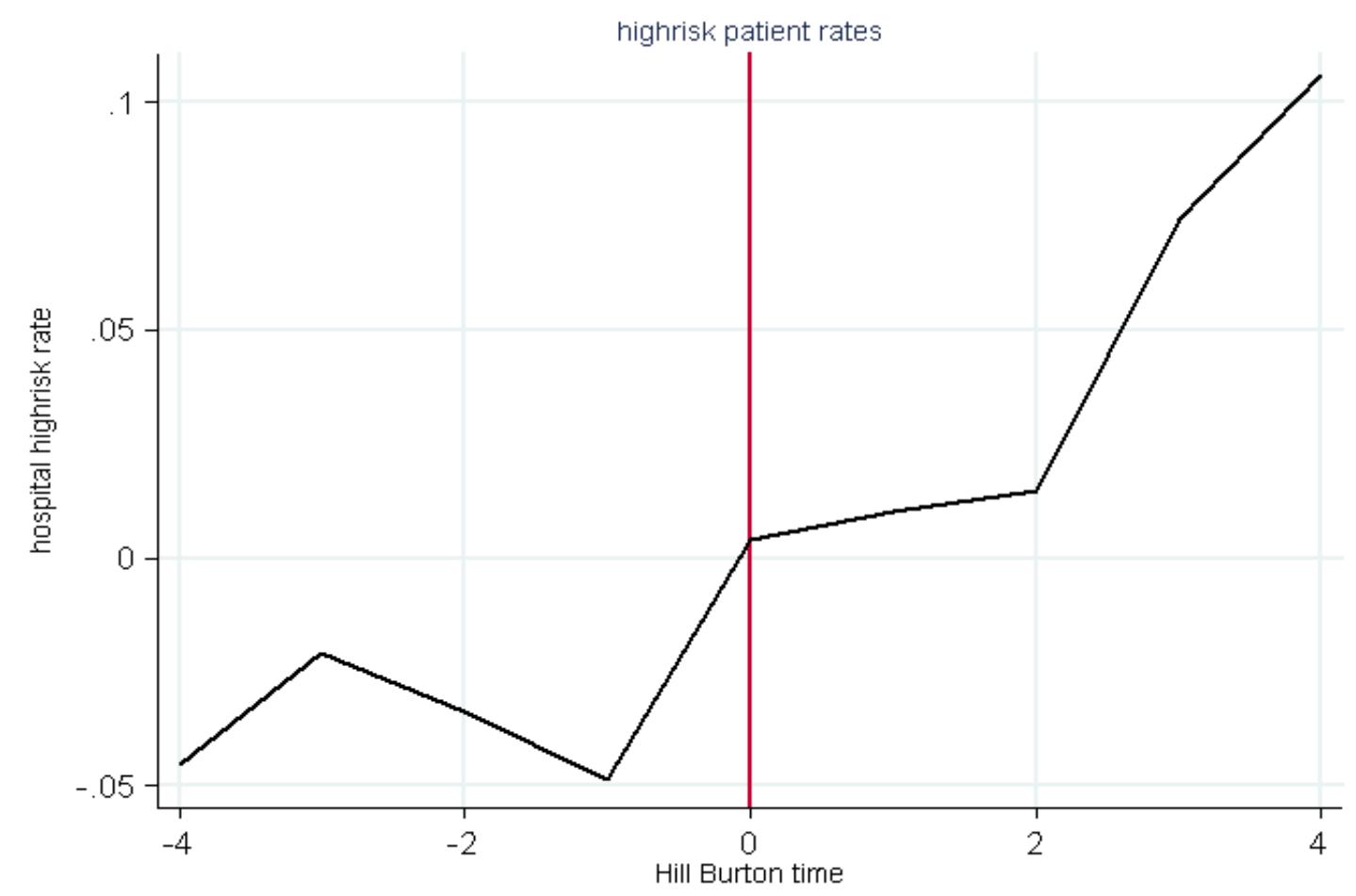

Note: Plots based on yearly averages of residuals from hospital-level regression of outcome on hospital and year fixed effects. Residuals are averaged across hospitals for every year of Hill-Burton obligation; balanced sample for -3 to +4 years after HB expiration. 
Table 1: Distribution of Births in Hill-Burton Hospitals and Hill-Burton Obligation Expirations by Year

\begin{tabular}{lllc}
\hline Year & $\begin{array}{l}\text { Percent births in HB } \\
\text { hospitals }\end{array}$ & N HB births & $\begin{array}{c}\text { N hospitals with obligations } \\
\text { expiring during the year }\end{array}$ \\
1989 & 17.72 & 14,529 & 6 \\
1990 & 14.83 & 13,922 & 1 \\
1991 & 11.67 & 11,169 & 2 \\
1992 & 10.71 & 10,493 & 1 \\
1993 & 8.7 & 8,840 & 5 \\
1994 & 4.98 & 5,018 & 2 \\
1995 & 3.59 & 3,623 & 1 \\
1996 & 2.96 & 3,002 & 2 \\
1997 & 2.8 & 2,919 & 1 \\
1998 & 2.71 & 2,862 & - \\
1999 & 2.74 & 2,822 & - \\
2000 & 2.64 & 2,690 & 1 \\
2001 & 1.98 & 1,894 & - \\
2002 & 2.04 & 1,767 & - \\
2003 & 1.94 & 1,497 & 1 \\
\hline
\end{tabular}


Table 2: Means of key variables

\begin{tabular}{|c|c|c|c|c|c|}
\hline & $\begin{array}{c}\begin{array}{c}\text { All singleton } \\
\text { births }\end{array} \\
\mathrm{N}=2321729\end{array}$ & $\begin{array}{c}\text { Birth to Mothers } \\
\text { with > } 2 \text { children } \\
N=1447624\end{array}$ & $\begin{array}{l}\text { Private Hospitals } \\
\qquad \begin{array}{c}\text { (moms }>2 \\
\text { children) } \\
\mathrm{N}=1084734\end{array}\end{array}$ & $\begin{array}{c}\text { Ever Hill Burton } \\
\text { Hospitals } \\
\text { (moms.>2 } \\
\text { children) } \\
\mathrm{N}=276419 \\
\end{array}$ & $\begin{array}{l}\text { Hill Burton births } \\
\text { (moms }>2 \\
\text { children) } \\
\mathrm{N}=87060\end{array}$ \\
\hline & \multicolumn{5}{|c|}{ Outcomes } \\
\hline & Mean & Mean & Mean & Mean & Mean \\
\hline Infant death & 0.009 & 0.010 & 0.009 & 0.011 & 0.011 \\
\hline Low birth weight & 0.069 & 0.064 & 0.059 & 0.067 & 0.067 \\
\hline Apgar score $<=8$ & 0.025 & 0.023 & 0.020 & 0.023 & 0.023 \\
\hline prenatal care in 1st trimester & 0.704 & 0.778 & 0.804 & 0.754 & 0.754 \\
\hline High risk pregnancy & 0.235 & 0.233 & 0.240 & 0.269 & 0.269 \\
\hline Complications of labor & 0.299 & 0.284 & 0.278 & 0.260 & 0.260 \\
\hline Premature child & 0.087 & 0.084 & 0.077 & 0.084 & 0.084 \\
\hline B/n 35 and 37 weeks & 0.051 & 0.050 & 0.048 & 0.049 & 0.042 \\
\hline B/n 32 and 35 weeks & 0.019 & 0.018 & 0.016 & 0.015 & 0.015 \\
\hline Less than 32 weeks & 0.015 & 0.015 & 0.013 & 0.016 & 0.012 \\
\hline Primary cesarean & 0.152 & 0.120 & 0.122 & 0.121 & 0.129 \\
\hline \multirow[t]{3}{*}{ Premature but not LBW } & 0.040 & 0.041 & 0.038 & 0.038 & 0.032 \\
\hline & \multicolumn{5}{|c|}{$\begin{array}{c}\text { Control } \\
\text { Variables }\end{array}$} \\
\hline & Mean & Mean & Mean & Mean & \\
\hline Hill-Burton birth & 0.056 & 0.060 & 0.080 & 0.315 & 1.00 \\
\hline \multirow{2}{*}{$\begin{array}{l}\text { Ratio HB in first county of } \\
\text { residence }\end{array}$} & 0.061 & 0.060 & 0.067 & 0.138 & 0.362 \\
\hline & {$[0.140]$} & {$[0.138]$} & {$[0.150]$} & {$[0.228]$} & {$[0.275]$} \\
\hline \multirow[t]{2}{*}{ Maternal age } & 26.932 & 26.550 & 26.911 & 26.439 & 25.936 \\
\hline & [6.292] & [5.933] & [5.849] & {$[5.957]$} & [5.711] \\
\hline \multirow[t]{2}{*}{ Interval previous birth } & 37.278 & 37.585 & 37.848 & 37.398 & 35.770 \\
\hline & [12.264] & [16.194] & [16.471] & [15.885] & [11.050] \\
\hline Black mother & 0.216 & 0.242 & 0.227 & 0.250 & 0.208 \\
\hline Hispanic mother & 0.172 & 0.178 & 0.180 & 0.128 & 0.140 \\
\hline$<$ high school education & 0.192 & 0.156 & 0.138 & 0.173 & 0.174 \\
\hline \multirow[t]{2}{*}{ Total fertility } & 2.125 & 2.623 & 2.754 & 2.824 & 2.896 \\
\hline & [1.18] & {$[1.127]$} & [1.133] & [1.182] & {$[1.205]$} \\
\hline Private hospital & 0.739 & 0.748 & 1.000 & 1.000 & 1.000 \\
\hline
\end{tabular}


Table 3: Hospital services by Hill-Burton status, Hospital Fixed Effects Regressions

\begin{tabular}{|c|c|c|c|c|}
\hline & \multicolumn{4}{|c|}{ Panel A: Hospital services } \\
\hline & (1) & (2) & (3) & (4) \\
\hline & $\begin{array}{l}\text { Have Maternity } \\
\text { ward }\end{array}$ & $\begin{array}{l}\text { Primary c- } \\
\text { section rate }\end{array}$ & $\begin{array}{l}\text { Ratio with } \\
\text { complications }\end{array}$ & $\begin{array}{l}\text { Ratio high } \\
\text { risk }\end{array}$ \\
\hline \multirow[t]{2}{*}{ Under HB obligation } & $0.145^{\star \star \star}$ & $-0.018^{\star \star}$ & $-0.066^{\star *}$ & $-0.076^{\star \star}$ \\
\hline & $(0.049)$ & $(0.007)$ & $(0.028)$ & $(0.031)$ \\
\hline \multirow[t]{2}{*}{ Constant } & 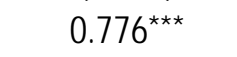 & $0.197^{\star \star \star}$ & $0.382^{\star \star \star}$ & $0.290^{\star \star \star}$ \\
\hline & $(0.040)$ & $(0.007)$ & $(0.024)$ & $(0.029)$ \\
\hline Observations & 1495 & 1272 & 1272 & 1272 \\
\hline \multirow[t]{3}{*}{ Mean of dep variable } & 0.914 & 0.156 & 0.303 & 0.261 \\
\hline & \multicolumn{4}{|c|}{ Panel B: Patient Demographics } \\
\hline & $\begin{array}{c}\text { Ratio <high } \\
\text { school }\end{array}$ & Ratio Black & Ratio Hispanic & \\
\hline \multirow[t]{2}{*}{ Under HB obligation } & 0.007 & 0.024 & -0.002 & \\
\hline & $(0.020)$ & $(0.016)$ & $(0.012)$ & \\
\hline \multirow[t]{2}{*}{ Constant } & $0.194^{\star \star \star}$ & $0.131^{\star \star \star}$ & 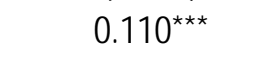 & \\
\hline & $(0.009)$ & $(0.015)$ & $(0.010)$ & \\
\hline Observations & 1272 & 1272 & 1272 & \\
\hline Mean of dep. Variable & 0.212 & 0.183 & 0.162 & \\
\hline
\end{tabular}

Notes: All regressions include year effects as well as hospital fixed effects. Hospitals are coded as under Hill-Burton obligations (Hill-Burton=1) if the year of delivery is prior to or equal to the year of expiration of hospital Hill-Burton obligations as reported by HRSA. The unit of observation is a hospital-year cell. Some hospital-year cell are missing data on NICU availability. The model for maternity wards includes all hospitalyear cells. The remaining models only hospital-year cells containing at least 100 births. Robust standard errors in parentheses. $A$ * indicates significance at the $10 \%$ level; ${ }^{* *}$ significance at the $5 \%$ level. 
Table 4: Fixed Effects Estimates of Hospital Selection Among Mothers who First Delivered in a Hill Burton Hospital

\begin{tabular}{lll}
\hline $\begin{array}{l}\text { All Hill-Burton } \\
\text { mothers }\end{array}$ & $\begin{array}{l}\text { Change of hospital } \\
\text { between births } \\
\text { FE }\end{array}$ & $\begin{array}{l}\text { Delivery in } \\
\text { private hospital } \\
\text { FE }\end{array}$ \\
$\begin{array}{l}\text { Birth is first post } \\
\text { HB expiration }\end{array}$ & $0.332^{\star \star \star}$ & $-0.088^{\star \star \star}$ \\
& $(0.065)$ & $(0.030)$ \\
$\begin{array}{l}\text { R-squared } \\
\begin{array}{l}\text { Mean of dep } \\
\text { variable }\end{array}\end{array}$ & 0.501 & 0.666 \\
\hline
\end{tabular}

Notes: There are 175,255 individual-level observations. The sample is restricted to mothers who had at least one delivery in a Hill-Burton hospital. Post Hill-Burton expiration is coded as 1 if the birth happened after the expiration of Hill- Burton obligations in the first Hill-Burton hospital of delivery and 0 otherwise. In addition to siblings fixed effects, all regressions include controls for male sex of the child, calendar year fixed effects, total birth order dummies, and birth interval dummies. Standard errors are bootstrapped and clustered on the hospital level. A * indicates significance at the $10 \%$ level; ** indicates significance at $5 \%$. 
Table 5: Fixed Effects and Fixed Effects-IV Estimates of the Effect of Delivery in a Hill-Burton Obligated Hospital and Infant Health

\begin{tabular}{|c|c|c|c|c|c|c|c|c|}
\hline & \multicolumn{2}{|c|}{ Infant death } & \multicolumn{2}{|c|}{$L B W$} & \multicolumn{2}{|c|}{ Low Apgar Score } & \multicolumn{2}{|c|}{ Premature } \\
\hline & 1 & 2 & 3 & 4 & 5 & 6 & 7 & 8 \\
\hline Panel 1 & $\mathrm{FE}$ & FE-IV & FE & FE-IV & FE & FE-IV & FE & FE-IV \\
\hline Hill Burton birth & $\begin{array}{l}-0.000 \\
(0.001)\end{array}$ & $\begin{array}{c}0.001 \\
(0.002)\end{array}$ & $\begin{array}{c}-0.004 \\
(0.003)\end{array}$ & $\begin{array}{l}-0.004 \\
(0.004)\end{array}$ & $\begin{array}{l}-0.002^{\star} \\
(0.001)\end{array}$ & $\begin{array}{l}-0.002 \\
(0.005)\end{array}$ & $\begin{array}{c}-0.009 * \star \star \\
(0.003)\end{array}$ & $\begin{array}{l}-0.017^{* \star} \\
(0.007)\end{array}$ \\
\hline \multirow{2}{*}{$\begin{array}{l}\text { Mean of dep. } \\
\text { variable }\end{array}$} & 0.010 & 0.010 & 0.064 & 0.064 & 0.023 & 0.023 & 0.084 & 0.084 \\
\hline & \multicolumn{2}{|c|}{$\begin{array}{l}\text { Less than } 32 \\
\text { weeks }\end{array}$} & \multicolumn{2}{|c|}{$\begin{array}{l}>=32 \text { and }<35 \\
\text { weeks }\end{array}$} & \multicolumn{2}{|c|}{$\begin{array}{c}>=35 \text { and }<37 \\
\text { weeks }\end{array}$} & \multicolumn{2}{|c|}{$\begin{array}{c}\text { Premature but not } \\
\text { LBW }\end{array}$} \\
\hline Hill-Burton birth & $\begin{array}{c}-0.002 \\
(0.001)\end{array}$ & $\begin{array}{l}-0.003 \\
(0.002)\end{array}$ & $\begin{array}{c}-0.002 \\
(0.001)\end{array}$ & $\begin{array}{l}-0.002 \\
(0.003)\end{array}$ & $\begin{array}{l}-0.006^{*} \\
(0.003)\end{array}$ & $\begin{array}{l}-0.011^{* *} \\
(0.005)\end{array}$ & $\begin{array}{c}-0.006^{\star *} \\
(0.003)\end{array}$ & $\begin{array}{c}-0.011^{\star *} \\
(0.005)\end{array}$ \\
\hline $\begin{array}{l}\text { Mean of dep. } \\
\text { variable }\end{array}$ & 0.015 & 0.015 & 0.018 & 0.018 & 0.050 & 0.050 & 0.041 & 0.041 \\
\hline
\end{tabular}

Notes: There are 1,446,624 individual-level observations. The first stage for the fixed effects-IV regressions has a coefficient estimate of $0.984(.002)$ on the instrument (FRAC_HB $B_{i t}$ ) which is the fraction of births that are in Hill-Burton obligated hospitals at time $t$ in the county in which we first observe the mother giving birth. Hospitals are coded as under Hill Burton obligations (Hill Burton=1) if the year of delivery is prior to or equal to the year of expiration of hospital Hill Burton obligations as reported by HRSA. In FE-IV regressions the Hill Burton treatment dummy is instrumented with the ratio of Hill Burton births in the first county of maternal residence. In addition to siblings fixed effects, all regressions include controls for male sex of the child, calendar year fixed effects, total birth order dummies, and birth interval dummies. Standard errors are bootstrapped and clustered on the hospital level. Robust standard errors are in parentheses. 
Table 6: Fixed Effects and Fixed Effects-IV Estimates of Differences in Procedure Rates and Maternal Selection by Hill Burton Status

\begin{tabular}{lcccccccc}
\hline All births & \multicolumn{2}{c}{$\begin{array}{c}\text { Primary C- } \\
\text { section }\end{array}$} & \multicolumn{2}{c}{ Complications } & \multicolumn{2}{c}{ High Risk mother } & \multicolumn{2}{c}{$\begin{array}{c}\text { Prenatal care visit in } \\
\text { the 1 } \text { 1t trimester }^{2}\end{array}$} \\
\hline & 1 & 2 & 3 & 4 & 5 & 6 & 7 & 8 \\
\hline Hill-Burton & -0.005 & $-0.026^{*}$ & -0.025 & -0.027 & -0.024 & -0.065 & $-0.018^{*}$ & .010 \\
Birth & $(0.009)$ & $(0.015)$ & $(0.024)$ & $(0.031)$ & $(0.026)$ & $(0.050)$ & $(0.010)$ & $(0.011)$ \\
$\begin{array}{l}\text { Mean of dep. } \\
\text { variable }\end{array}$ & 0.120 & 0.120 & 0.284 & 0.284 & 0.233 & 0.233 & 0.778 & 0.778 \\
\hline
\end{tabular}

Notes: There are 1,447,624 individual-level observations. The first stage for the fixed effects-IV regressions has a coefficient estimate of $0.984(.002)$ on the instrument (FRAC_HB $B_{i t}$ ) which is the fraction of births that are in Hill-Burton obligated hospitals at time $t$ in the county in which we first observe the mother giving birth. Hospitals are coded as under Hill Burton obligations (Hill Burton=1) if the year of delivery is prior to or equal to the year of expiration of hospital Hill Burton obligations as reported by HRSA. In addition to siblings fixed effects, all regressions include controls for male sex of the child, calendar year fixed effects, total birth order dummies, and birth interval dummies. Cluster-robust standard errors in parentheses. A * indicates significant at 10\%; ** significant at 5\%. Standard errors are bootstrapped and clustered at the hospital level. 
Appendix Tables:

Table A1 Hill Burton and Individual Health Outcomes - OLS Regressions

\begin{tabular}{lcccc}
\hline & Infant death & LBW & $\begin{array}{c}\text { Low Apgar } \\
\text { Score }\end{array}$ & Premature \\
\hline \multirow{3}{*}{ Hill Burton } & OLS & OLS & OLS & OLS \\
& -.000 & -.005 & -.003 & $-.013^{\star *}$ \\
\# Observations & $(.001)$ & $(.004)$ & $(.003)$ & $(.005)$ \\
\hline
\end{tabular}

Notes: Hospitals are coded as under Hill Burton obligations (Hill Burton=1) if the year of delivery is prior to or equal to the year of expiration of hospital Hill Burton obligations as reported by HRSA. All regressions include controls for male sex of the child, calendar year fixed effects, total birth order dummies, birth interval dummies, controls for black race and Hispanic ethnicity, a dummy indicating less than high school education, and total fertility dummies. Standard errors are bootstrapped and clustered on the hospital level. Standard errors in parentheses. A * indicates significance at $10 \%$, ${ }^{* *}$ significance at $5 \%$, ${ }^{* \star}$ significance at $1 \%$. 
Table A2: Hill Burton and Individual Health Outcomes Hispanics only

\begin{tabular}{|c|c|c|c|c|c|c|c|c|}
\hline & \multicolumn{2}{|c|}{ Infant Death } & \multicolumn{2}{|c|}{ LBW } & \multicolumn{2}{|c|}{ Low Apgar score } & \multicolumn{2}{|c|}{ Premature } \\
\hline & 1 & 2 & 3 & 4 & 5 & 6 & 7 & 8 \\
\hline & $\mathrm{FE}$ & FE-IV & FE & FE-IV & FE & FE-IV & $\mathrm{FE}$ & FE-IV \\
\hline \multirow[t]{3}{*}{ Hill Burton } & 0.002 & -0.011 & -0.003 & -0.002 & -0.002 & -0.009 & $-0.011^{*}$ & $-0.042^{*}$ \\
\hline & $(0.004)$ & $(0.008)$ & $(0.006)$ & $(0.018)$ & $(0.005)$ & $(0.009)$ & $(0.006)$ & $(0.022)$ \\
\hline & Less tha & Neeks & $>=32 \mathrm{ar}$ & 35 weeks & $>=35$ & 37 weeks & \multicolumn{2}{|c|}{$\begin{array}{c}\text { Premature but not } \\
\text { LBW }\end{array}$} \\
\hline \multirow[t]{2}{*}{ Hill Burton } & -0.002 & -0.004 & -0.002 & $-0.017^{\star *}$ & -0.007 & -0.033 & -0.008 & -0.033 \\
\hline & $(0.006)$ & $(0.010)$ & $(0.003)$ & $(0.009)$ & $(0.008)$ & $(0.021)$ & $(0.007)$ & $(0.021)$ \\
\hline \# Obs. & 258774 & 258774 & 258774 & 258774 & 258774 & 258774 & 258774 & 258774 \\
\hline \multicolumn{9}{|c|}{ Blacks only } \\
\hline & \multicolumn{2}{|c|}{ Infant Death } & \multicolumn{2}{|c|}{ LBW } & \multicolumn{2}{|c|}{ Low Apgar score } & \multicolumn{2}{|c|}{ Premature } \\
\hline \multirow[t]{4}{*}{ Hill Burton } & -0.001 & 0.003 & -0.011 & -0.013 & -0.004 & -0.005 & $-0.020^{\star \star}$ & $-0.029^{\star}$ \\
\hline & $(0.002)$ & $(0.005)$ & $(0.008)$ & $(0.010)$ & $(0.004)$ & $(0.008)$ & $(0.010)$ & $(0.016)$ \\
\hline & & & & & & & \multirow{2}{*}{\multicolumn{2}{|c|}{$\begin{array}{l}\text { Premature but not } \\
\text { LBW }\end{array}$}} \\
\hline & Less tha & Neeks & $>=32 \mathrm{ar}$ & 35 weeks & $>=35$ anc & weeks & & \\
\hline \multirow[t]{2}{*}{ Hill Burton } & -0.005 & -0.004 & -0.005 & -0.008 & $-0.011^{*}$ & $-0.016^{\star}$ & -0.010 ** & $-0.013^{*}$ \\
\hline & $(0.004)$ & $(0.005)$ & $(0.004)$ & $(0.007)$ & $(0.006)$ & $(0.009)$ & $(0.004)$ & $(0.007)$ \\
\hline \# Obs. & 380160 & 380160 & 380160 & 380160 & 380160 & 380160 & 380160 & 380160 \\
\hline
\end{tabular}

Notes: Hospitals are coded as under Hill Burton obligations (Hill Burton=1) if the year of delivery is prior to or equal to the year of expiration of hospital Hill Burton obligations as reported by HRSA. In FE-IV regressions the Hill Burton treatment dummy is instrumented with the ratio of Hill Burton births in the first county of maternal residence. In addition to siblings fixed effects, all regressions include controls for male sex of the child, calendar year fixed effects, total birth order dummies, and birth interval dummies. Standard errors are bootstrapped and clustered on the hospital level.

Robust standard errors in parentheses. A * indicates significant at 10\%; ** significant at 5\%; ** significant at $1 \%$. 
Table A3: Differences in procedure rates by Hill Burton status

\begin{tabular}{lcccccccc}
\hline & \multicolumn{2}{c}{ Primary } & C-section & \multicolumn{2}{c}{ Complications } & \multicolumn{2}{c}{ High Risk mother } & \multicolumn{2}{c}{$\begin{array}{c}\text { Prenat care visit 1st } \\
\text { trimester }\end{array}$} \\
\hline & 1 & 2 & 3 & 4 & 5 & 6 & 7 & 8 \\
\hline Hispanics & FE & FE-IV & FE & FE-IV & FE & FE-IV & FE & FE-IV \\
\hline HB Child & 0.023 & 0.012 & $0.051^{*}$ & 0.010 & $0.050^{*}$ & -0.124 & $-0.060^{\star \star *}$ & -0.029 \\
& $(0.023)$ & $(0.044)$ & $(0.029)$ & $(0.073)$ & $(0.029)$ & $(0.079)$ & $(0.019)$ & $(0.050)$ \\
\hline Obs & 258774 & 258774 & 258774 & 258774 & 258774 & 258774 & 258774 & 258774 \\
\hline & & & & & & & & \\
\hline Blacks & & & & & & & & \\
\hline HB Child & -0.010 & $-0.024^{\star *}$ & -0.024 & 0.009 & -0.037 & -0.077 & -0.000 & $0.039^{*}$ \\
& $(0.009)$ & $(0.011)$ & $(0.035)$ & $(0.048)$ & $(0.041)$ & $(0.081)$ & $(0.015)$ & $(0.022)$ \\
\hline Obs & 380160 & 380160 & 380160 & 380160 & 380160 & 380160 & 380160 & 380160 \\
\hline
\end{tabular}

Notes: The first stage for the fixed effects-IV regressions has a coefficient estimate of $0.984(.002)$ on the instrument (FRAC_HB $\mathrm{B}_{\mathrm{it}}$ ) which is the fraction of births that are in Hill-Burton obligated hospitals at time $t$ in the county in which we first observe the mother giving birth. Hospitals are coded as under Hill Burton obligations (Hill Burton=1) if the year of delivery is prior to or equal to the year of expiration of hospital Hill Burton obligations as reported by HRSA. In addition to siblings fixed effects, all regressions include controls for male sex of the child, calendar year fixed effects, total birth order dummies, and birth interval dummies. : Robust standard errors in parentheses. A * indicates significance at 10\%; ** significant at $5 \%$. Standard errors are bootstrapped and clustered at the hospital level. 
Table A4: Sibling Fixed Effects Models of Hospital selection

\begin{tabular}{lllll}
\hline & $\begin{array}{l}\text { Change of hospital } \\
\text { - Hispanics }\end{array}$ & $\begin{array}{l}\text { Delivery in private } \\
\text { hospital - } \\
\text { Hispanics }\end{array}$ & $\begin{array}{l}\text { Change of } \\
\text { hospital- Blacks }\end{array}$ & $\begin{array}{l}\text { Delivery in private } \\
\text { hospital - Blacks }\end{array}$ \\
\hline $\begin{array}{l}\text { Post first HB } \\
\text { expiration }\end{array}$ & $0.425^{\star * *}$ & $-0.126^{* \star *}$ & $0.305^{\star * \star}$ & $-0.106^{* \star}$ \\
Observations & $(0.063)$ & $(0.047)$ & $(0.091)$ & $(0.048)$ \\
\hline R-squared & 22927 & 22927 & 43126 & 43126 \\
\hline
\end{tabular}

Notes: The sample is restricted to mothers who had at least one delivery in a Hill Burton hospital. Post Hill Burton expiration is coded as 1 if the birth happened after the expiration of Hill Burton obligations in the first Hill Burton hospital of delivery and 0 otherwise. In addition to siblings fixed effects, all regressions include controls for male sex of the child, calendar year fixed effects, total birth order dummies, and birth interval dummies. Standard errors are bootstrapped and clustered on the hospital level. Robust standard errors in parentheses. A * indicates significant at 10\%; ** significant at 5\%. 